\title{
Can chaetognath fecal pellets contribute significantly to carbon flux?
}

\author{
Lisa Dilling, Alice L. Alldredge \\ Department of Biological Sciences and Marine Science Institute, University of California, Santa Barbara, \\ Calíiornia 93106, USA
}

\begin{abstract}
The high abundance of chaetognaths and the relatively large size of their fecal pellets suggest that these planktonic predators might make a substantial contribution to vertical carbon flux in some regions. Although fecal pellets of the epipelagic species Parasagitta euneritica and the mesopelagic species Solidosagitta zetesios and Pseudosagitta maxima had high sinking speeds, 27 to $1313 \mathrm{~m}$ $\mathrm{d}^{-1}$, they sank 5 to 10 times more slowly than comparably sized herbivore fecal pellets. Chaetognath fecal pellets had densities around $1.035 \mathrm{~g} \mathrm{~cm}^{-3}$ Estimates using published pellet production rates and animal abundances, and measured pellet carbon content show that chaetognath fecal pellets could contribute modestly $(4$ to $6 \%$ ) to carbon flux in the euphotic zone and substantially $(6$ to $60 \%)$ at depth.
\end{abstract}

\section{INTRODUCTION}

The abundance and sinking velocities of large particles, such as fecal pellets and marine snow (detrital aggregates larger than $500 \mu \mathrm{m}$ in diameter), determine the magnitude of carbon flux which reaches the benthos (Fowler \& Knauer 1986). Due to their high sinking speeds, large particles are not consumed or remineralized in the water column as readily as small, suspended particles. Fecal pellets in particular have been hypothesized to play an important role in carbon flux to the benthos, since they are one of the few types of particles with sufficient mass and sinking speeds to be removed rapidly from surface waters.

Several predominantly herbivorous zooplankton, including salps, euphausiids, large copepods, and pteropods, produce large, rapidly sinking fecal pellets (Wiebe et al. 1979, Bruland \& Silver 1981, Anderson \& Nival 1988). Predatory zooplankton also produce relatively large fecal pellets. The most abundant planktonic predators in many areas of the ocean are chaetognaths, which produce large compact fecal pellets enclosed in a membrane (Reeve et al. 1975). Densities of 500 ind. $\mathrm{m}^{-3}$ have been reported off the California (USA) coast (Mullin 1979), while more typical oceanic densities range from 20 to 50 ind. $\mathrm{m}^{-3}$ (Star \& Mullin
1981). While the role of fecal pellets produced by predatory zooplankton in carbon cycling in the ocean has been largely unexplored, the abundant and ubiquitous distribution of chaetognaths and the characteristics of their fecal matter suggest that they may, in particular, be important sources of sinking particles.

In this study we investigated the hypothesis that chaetognath fecal pellets could contribute significantly to carbon flux. We determined fecal pellet carbon content and sinking speeds, and combined this information with published values on feeding rates and abundance to estimate pellet fluxes to different zones in the water column.

\section{METHODS}

Epipelagic chaetognaths of the common species Parasagitta euneritica Alvariño were obtained throughout 1991 and 1992 using a $0.75 \mathrm{~m}$ diameter plankton net with $500 \mu \mathrm{m}$ mesh. Specimens were collected in April of both years off Point Conception, California and in August, October, November, December 1991 and February 1992 in the Santa Barbara Channel, California. While the larger mesh size probably did not retain some smaller chaetognaths, it also 
did not retain most prey items so that within-net feeding was minimized. Specimens with prey items in their guts were removed from the transparent cod ends using a large-bore pipette, placed into beakers containing $5 \mu \mathrm{m}$ filtered seawater, and allowed to defecate at $5^{\circ} \mathrm{C}$ overnight. Supplementary data on chaetognath abundances were gathered in the Santa Barbara Channel using a $1 \mathrm{~m}$ diameter net with $333 \mu \mathrm{m}$ mesh equipped with a General Oceanics Inc. flowmeter (model 2030R) suspended in the mouth opening.

Mesopelagic chaetognaths of the species Pseudosagitta maxima Conant and Solidosagitta zetesios Fowler were collected in deep water off the central coast of California in July 1991 and June 1992. A $10 \mathrm{~m}^{2}$ Tucker trawl with 301 thermally protecting cod end (Childress et al. 1978) was towed at a speed of less than 1 knot to minimize damage to the specimens. Chaetognaths were selected by hand, placed into beakers of tiltered seawater and allowed to defecate at $5^{\circ} \mathrm{C}$ for at least $36 \mathrm{~h}$.

Fecal pellets were collected at the end of the incubation from the beakers by pipette. The amount of degradation which might have taken place after the relatively short period at that temperature was assumed to be negligible (Honjo \& Roman 1978). Pellet sinking rates were determined in a 21 gimbled graduated cylinder filled with filtered seawater at room temperature $\left(20^{\circ} \mathrm{C}\right)$ to minimize convection currents. As each pellet sank, 4 or 5 consecutive measurements of the time required for the pellet to sink a distance of $1.6 \mathrm{~cm}$ through the cylinder were determined with a stopwatch. Sinking speed was measured on a total of 11 pellets from Parasagitta euneritica and 20 pellets from the 2 midwater species.

Additional pellets were rinsed in distilled water, placed onto pre-weighed nuclepore filters, dried at $75^{\circ} \mathrm{C}$ for $24 \mathrm{~h}$ and reweighed on a CAHN Electrobalance (Model 4600) to obtain dry weights. Pellets were also rinsed and collected onto pre-weighed, ashed foil boats or GF/F filters, dried in a drying oven, and stored in a dessicator for CHN content determination with a Leeman Labs Inc. CE CHN Analyzer (Model 440). (See Table 1 for numbers of pellets analyzed.) Chaetognaths and fecal pellets were sized using calipers and a dissecting microscope with micrometer.

To corroborate measured sinking rates, densities of individual pellets were measured independently at a controlled temperature of $15^{\circ} \mathrm{C}$ by suspending them in seawater layered over a series of Percoll solutions of different density (Pennington \& Strathmann 1990). Crystalline $\mathrm{NaCl}$ was added to pure Percoll, to match the osmolarity of seawater at $33 \%$ and then diluted with filtered seawater to produce solutions of 5 densities. A total of 28 pellets were gently dropped into the top seawater layer in 28 individual test tubes. These test tubes contained seawater layered over 8 solutions at $1.025 \mathrm{~g} \mathrm{~cm}^{-3}, 4$ at $1.03 \mathrm{~g} \mathrm{~cm}^{-3}, 5$ at $1.035 \mathrm{~g} \mathrm{~cm}^{-3}, 8$ at $1.04 \mathrm{~g} \mathrm{~cm}^{-3}$ and 3 at $1.1 \mathrm{~g} \mathrm{~cm}^{-3}$. If they sank through both layers, their density was recorded as greater than the solution in the test tube, and if they were suspended at the interface of the Percoll and seawater, it was recorded as less than that of the solution. In this way, a density range for fecal pellets from epipelagic chaetognaths was determined. While this method does not give precise density information, it does allow comparison with estimates based on sinking rates, and gives an adequate range to distinguish gross density differences between chaetognath pellets and herbivorous zooplankton pellets. The density of mesopelagic chaetognath pellets was not measured.

Pellet production rate was estimated using published daily prey rations. Daily prey rations can be estimated from gut transit time and percent of specimens containing prey at a given time. Since gut transit time was not measured in this study, daily prey ration could not be directly derived. Instead, the percent of individuals containing prey in this study was compared with results of published studies to decide if literature values for daily prey ration could be used, assuming digestion time was similar. In this study, the percent of all species containing food in their guts was determined by examining live chaetognaths by eye captured throughout a $24 \mathrm{~h}$ period.

\section{RESULTS}

Pellets of Parasagitta euneritica, the common neritic species off the central coast of California, were characterised by a long and slender shape, tapering at one end to a thin, tail-like structure (Fig. 1a). Much of the pellet was highly translucent with regions of opaque or pigmented material. Copepod body parts, when present, were visible through the membrane. In addition, all pellets were extremely sticky and had to be handled in water.

Pellets from the midwater species, Pseudosagitta maxima and Solidosagitta zetesios, varied in appearance, with some resembling those of Parasagitta euneritica, and others more square in shape (Fig. 1b). Many of the pellets had an orange coloration, presumably a reflection of their midwater prey, which often have orange pigments. S. zetesios feeds mainly on copepods and other chaetognaths, with euphausiids and ostracods being minor components of the diet (Terazaki \& Marumo 1982).

Sizes, dry weights, carbon contents, and $C: N$ ratios of chaetognath pellets are detailed in Table 1. Pellets from the 2 midwater species were much larger than 

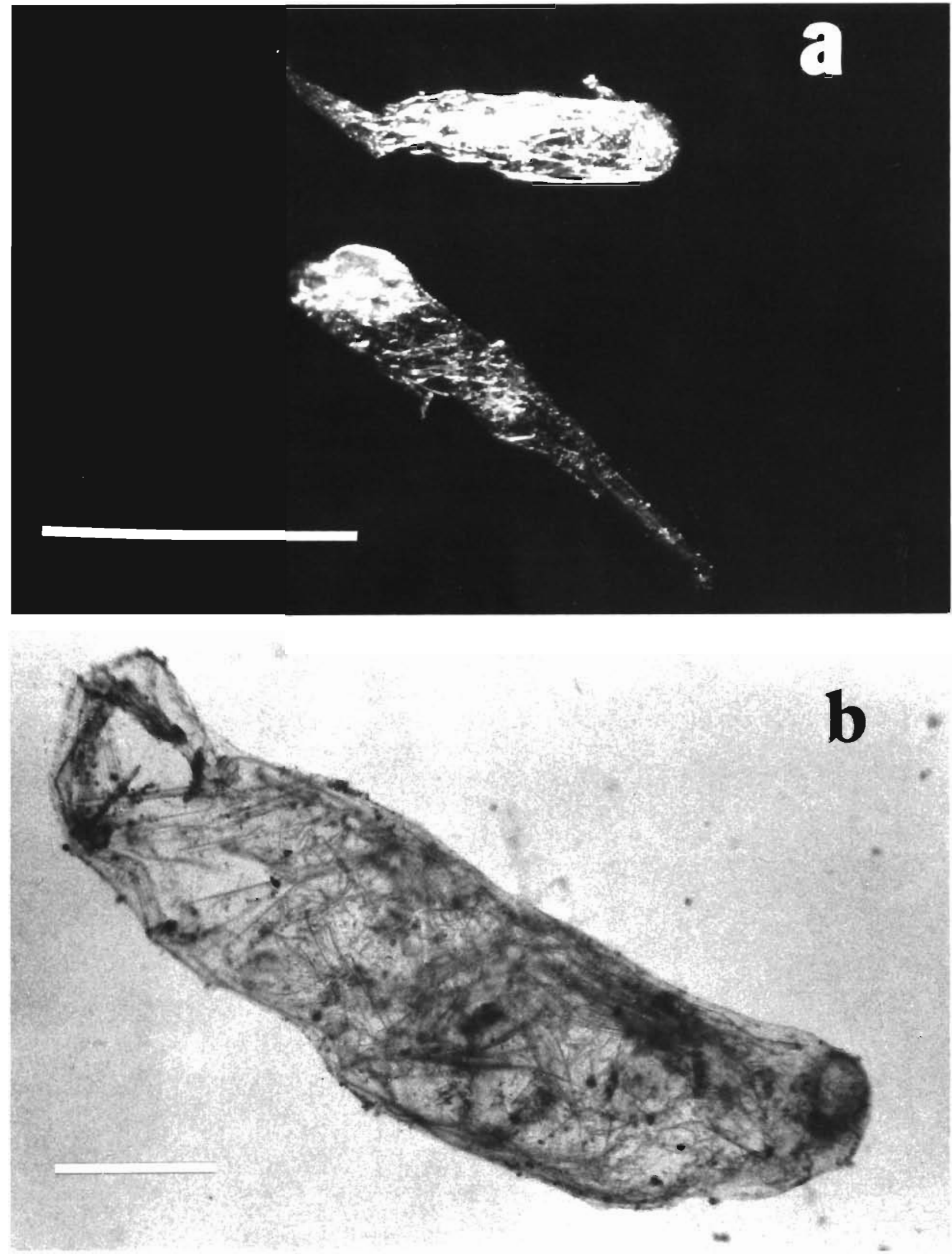

Fig. 1. Chaetognath fecal pellets. (a) Pellet of Parasagitta euneritica. Scale bar $=1 \mathrm{~mm}$. (b) Pellet of midwater species, Solidosagitta zetesios. Scale bar $=1 \mathrm{~mm}$. Note that the tapered, tail-like structure on this pellet has been folded and is stuck to the main body of the pellet 
Table 1 Pellet characteristics of epipelagic (Parasagitta euneritica) and midwater (Pseudosagitta maxima and Solidosagitta zetesios) chaetognaths

\begin{tabular}{|c|c|c|c|c|}
\hline Parameter & $\begin{array}{l}\text { Mean } \\
( \pm S D)\end{array}$ & No. of samples & $\begin{array}{l}\text { No. of pellets } \\
\text { sample }\end{array}$ & $\begin{array}{c}\text { Total no. of } \\
\text { pellets sampled }\end{array}$ \\
\hline \multicolumn{5}{|l|}{ Epipelaqic species } \\
\hline Length of pellet $(\mathrm{mm})$ & $1.3 \pm 0.3$ & 62 & 1 & 62 \\
\hline Width of pellet ( $\mathrm{mm}$ ) & $0.3 \pm 0.1$ & 62 & 1 & 62 \\
\hline Dry wt pellet ${ }^{-1}(\mu \mathrm{g})$ & $7.9 \pm 1.5$ & 5 & $5-8$ & 35 \\
\hline $\mathrm{C}$ content ( $\mu \mathrm{g}$ pellet $\left.{ }^{-1}\right)$ & $0.9 \pm 0.3$ & 6 & $8-20$ & 82 \\
\hline$N$ content $\left(\mu\right.$ pellet $\left.^{-1}\right)$ & $0.2 \pm 0.1$ & 5 & $8-20$ & 66 \\
\hline $\mathrm{C}: \mathrm{N}$ ratio (by weight) & $7.2 \pm 1.8^{a}$ & 5 & $8-20$ & 66 \\
\hline \multicolumn{5}{|l|}{ Midwater species } \\
\hline Length of pellet (mm) & $3.9 \pm 1.4$ & 20 & 1 & 20 \\
\hline Width of pellet (mm) & $1.5 \pm 0.6$ & 20 & 1 & 20 \\
\hline Dry wt pellet ${ }^{-1}(\mu \mathrm{q})$ & $102.7 \pm 66$ & 2 & $11-13$ & 24 \\
\hline $\mathrm{C}$ content (ug pellet ${ }^{-1}$ ) & $45.8 \pm 16.8$ & 6 & $4-13$ & 53 \\
\hline $\mathrm{N}$ content $\left(\mu \mathrm{g}\right.$ pellet $\left.^{-1}\right)$ & $5.8 \pm 3.4$ & 6 & $4-13$ & 53 \\
\hline C: N ratio (by weight) & $9.1 \pm 3.8^{a}$ & 6 & $4-13$ & 53 \\
\hline
\end{tabular}

those of Parasagitta euneritica, reflecting the larger body size of the midwater species. Midwater pellets had 50 times more carbon and a higher $\mathrm{C}: \mathrm{N}$ ratio than $P$. euneritica pellets.

The sinking rates of fecal pellets from epipelagic chaetognaths ranged from 27 to $196 \mathrm{~m} \mathrm{~d}^{-1}$, with a mean of $58 \pm 49$ (SD) (Fig. 2). The sinking rates of fecal pellets from midwater species ranged from 83 to $1313 \mathrm{~m} \mathrm{~d}^{-1}$ with a mean of $382 \pm 306$. Both groups had sinking rates which varied by an order of magnitude. Sinking rates increased significantly with pellet size, $\left(r^{2}=0.62, p<0.01\right)$ (Fig. 2). Approximately $15 \%$ of the

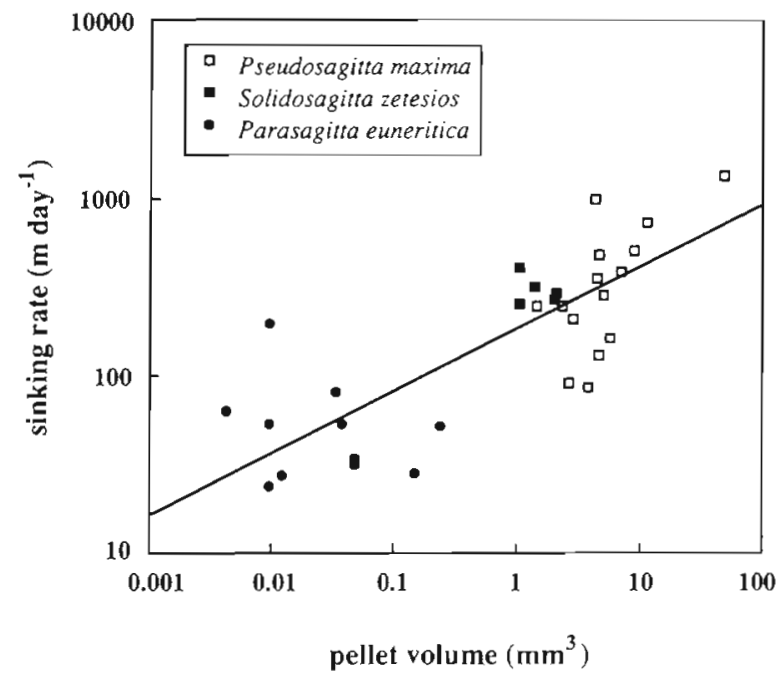

Fig. 2. Sinking rates of epipelagic species Parasagitta euneritica and midwater species Pseudosagitta maxima and Solidosagitta zetesios increase as a function of pellet size $\left(r^{2}=0.62 \cdot p<0.01\right)$ fecal pellets of midwater species and $5 \%$ of the pellets of epipelagic species did not sink at all, remaining neutrally buoyant or floating to the surface of the container. These pellets were not included in the sinking rate or density measurements.

The measured density of Parasagitta euneritica fecal pellets was ca $1.035 \mathrm{~g} \mathrm{~cm}^{-3}$ (Table 2). This is close to the mean density of $1.04 \pm 0.02 \mathrm{~g} \mathrm{~cm}^{-3}$ (SD) calculated with the formula of Komar et al. (1981) using sinking rates and volumes of 11 epipelagic pellets.

The proportion of animals that contained prey, i.e. the food-containing ratio (FCR), was consistent with values reported for other epipelagic species (Fig. 3). Epipelagic chaetognaths do not generally contain more than one prey item at a time and gut transit time ranges from 1 to 3 h (Szyper 1978, Feigenbaum 1979, Nagasawa 1985). Chaetognaths also tend to process their prey discontinuously rather than on a constant basis (Reeve et al. 1975). It was assumed, therefore, that the number of pellets produced per day is equal to

Table 2. Primary density of Parasagitta euneritica fecal pellets as measured by a series of Percoll solutions of different density

\begin{tabular}{|lccc|}
\hline $\begin{array}{l}\text { Density of } \\
\text { solution } \\
\left(\mathrm{g} \mathrm{cm}^{-3}\right)\end{array}$ & $\begin{array}{c}\text { No. of pellets with density: } \\
\text { Less than } \\
\text { solution }\end{array}$ & $\begin{array}{c}\text { More than } \\
\text { solution }\end{array}$ & $\begin{array}{c}\text { Total no. of } \\
\text { pellets tested } \\
\text { in each } \\
\text { solution }\end{array}$ \\
\hline 1.025 & 0 & $8(100 \%)$ & 8 \\
1.03 & 0 & $4(100 \%)$ & 4 \\
1.035 & $3(60 \%)$ & $2(40 \%)$ & 5 \\
1.04 & $7(88 \%)$ & $1(12 \%)$ & 8 \\
1.1 & $3(100 \%)$ & 0 & 3 \\
\hline
\end{tabular}




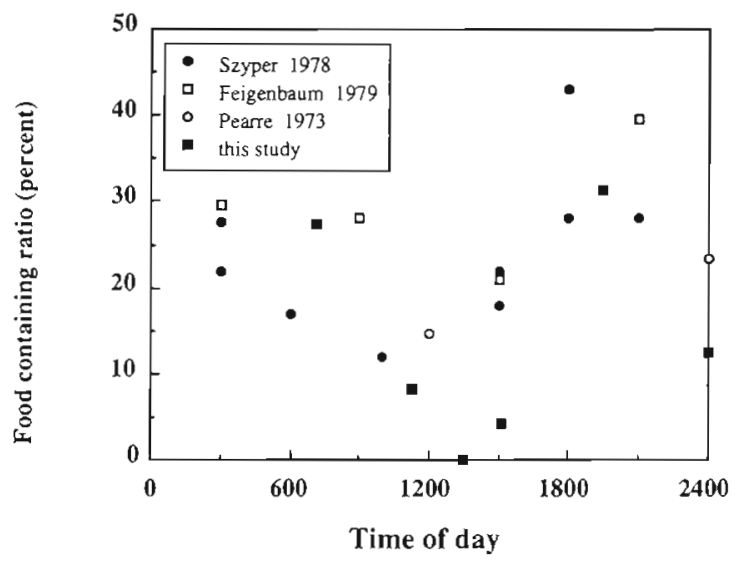

Fig. 3. The diel cycle of feeding in Parasagitta euneritica from this study with literature values for other epipelagic species. A total of 234 specimens were examined

the daily prey ration. A conservative estimate of daily prey ration of 2 prey $\mathrm{d}^{-1}$ (and thus 2 pellets produced $\mathrm{d}^{-1}$ ) was obtained from the literature and used in the flux estimates for the epipelagic zone.

The FCR of Pseudosagitta maxima ranged from 13 to $33 \%$ (Fig. 4). This range is higher than the $8.7 \%$ FCR reported for Solidosagitta zetesios (Terazaki \& Marumo 1982). Although the mesh size of the net did not retain many prey items of the appropriate size, the high FCR reported here may reflect some net feeding since the net was towed for as long as $4 \mathrm{~h}$ in order to obtain a high enough concentration of animals from the mesopelagic zone. Digestion time for mesopelagic chaetognaths is not known, but since the animals are 2 to 4 times longer than epipelagic species, and live at

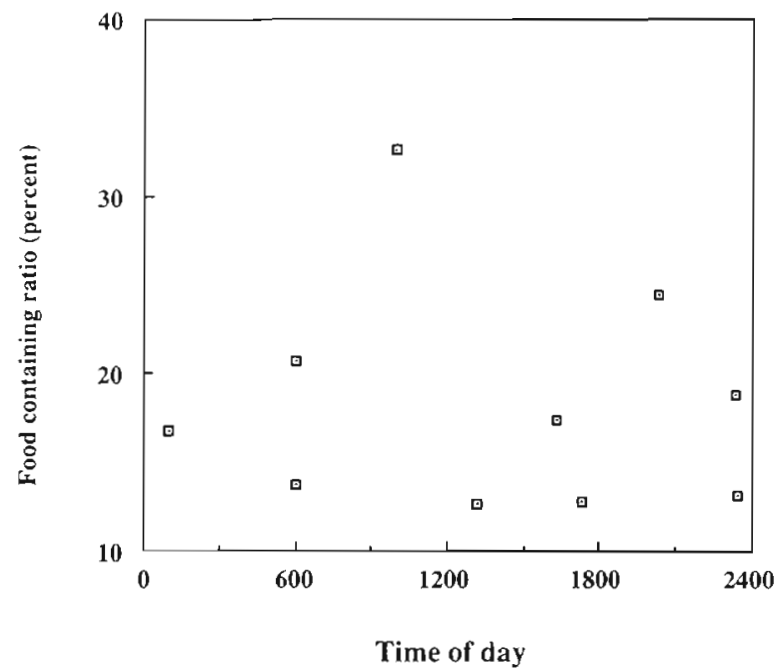

Fig. 4. The diel feeding cycle in Pseudosagitta maxima, collected between 500 and $1000 \mathrm{~m}$. A total of 377 specimens were examined lower temperatures under lower food concentrations, they may have a slower digestion time. In order to estimate the contribution of midwater chaetognath fecal pellets to flux from the mesopelagic zone, a conservative daily ration of 1 prey $\mathrm{d}^{-1}$ (and thus 1 pellet $\mathrm{d}^{-1}$ ) was used.

\section{DISCUSSION}

Chaetognath fecal pellets sink rapidly enough (27 to $1313 \mathrm{~m} \mathrm{~d}^{-1}$ ) to be important components of carbon flux. These pellets sink more slowly than similarly-sized herbivore pellets, however. Using the data compiled by Bruland \& Silver (1981) we calculate that comparably-sized herbivore pellets sink roughly 10 times faster than epipelagic chaetognath pellets and 5 times faster than midwater chaetognath pellets (Fig. 5). Volume was calculated as an ellipsoid, which is the closest geometric shape to approximate chaetognath pellets.

One reason chaetognath pellets might sink more slowly for a given size is that their density or specific gravity is lower. Particle density is a major variable determining a particle's sinking rate (Komar et al. 1981). For comparison, euphausiid fecal pellet densities are around $1.23 \mathrm{~g} \mathrm{~cm}^{-3}$ (Komar et al. 1981), considerably higher than chaetognath pellet densities reported here $\left(1.035 \mathrm{~g} \mathrm{~cm}^{-3}\right)$.

Density difference may result from differences in content and packaging; pellets containing exoskeletal copepod remains may be packed less tightly than pellets containing the remains of phytoplankton cells. The shape of the pellet may be constrained by the undi-

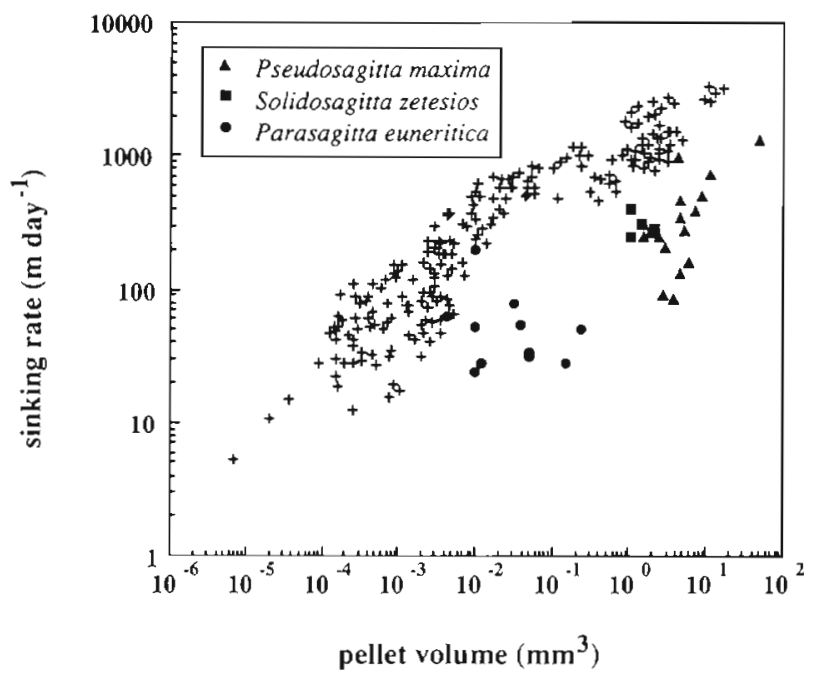

Fig. 5. Sinking rates of chaetognath fecal pellets compared to herbivore pellets (t: including copepods, nauplii, euphausiids, pteropods and salps; from Bruland \& Silver 1981) 
Table 3. Potential percent contribution of chaetognath fecal pellets to carbon flux out of the euphotic zone in 2 production regimes

\begin{tabular}{|c|c|c|}
\hline & $\begin{array}{l}\text { Upwelling region } \\
\text { (Coastal California) }\end{array}$ & $\begin{array}{c}\text { Oligotrophic region } \\
\text { (North Pacific Central Gyre) }\end{array}$ \\
\hline Carbon ( $\mu g$ pellet ${ }^{-1}$ ) & $0.9^{\mathrm{d}}$ & $0.9^{\circ}$ \\
\hline No. of pellets $d^{-1}$ & $2^{b}$ & $2^{b}$ \\
\hline Total pellet $\mathrm{C}$ ( $\mu \mathrm{g}$ ind. ${ }^{-1}$ ) & 1.8 & 1.8 \\
\hline \multicolumn{3}{|l|}{ No of ind $\mathrm{m}^{-3}$ in: } \\
\hline upper euphotic zone $0-35$ or $50 \mathrm{~m}$ & $32^{c}-116^{d}$ & $32^{\mathrm{e}}$ \\
\hline lower euphotic zone 35 or $50-100 \mathrm{~m}$ & $3.8-7.5^{1}$ & $0.5^{9}$ \\
\hline Fecal carbon production rate $\left(\mathrm{mg} \mathrm{m}^{-2} \mathrm{~d}^{-1}\right)$ & $2.8-10.8$ & 2.1 \\
\hline Total daily particulate flux at $100 \mathrm{~m}\left(\mathrm{mg} \mathrm{C} \mathrm{m}^{-2} \mathrm{~d}^{-1}\right)$ & $259^{\mathrm{h}}$ & $35.6^{1}$ \\
\hline$\%$ pellet of total flux & $1.1-4.2$ & 5.9 \\
\hline
\end{tabular}

gested exoskeleton, preserving some spaces within the pellet. The degrec of packing, however, was not estimated in this study. In addition, chitin and other components of the exoskeleton are less dense than diatom frustules, coccoliths and other phytoplankton remains. Chitin has a density of 1.4 to $1.42 \mathrm{~g} \mathrm{~cm}^{-3}$ (Rudall 1963), while the siliceous frustules of diatoms have a density of $2.6 \mathrm{~g} \mathrm{~cm}^{-3}$ (Smayda 1970). Moreover, the contents of chaetognath pellets change with the type of prey ingested, and may account for some of the variation in size and sinking rate.

Midwater chaetognath pellets in particular may be less dense than herbivore pellets because of the characteristics of their prey. Midwater crustaceans have been shown to have a higher lipid content as well as a higher relative buoyancy than shallower dwelling crustaceans (Childress \& Nygaard 1974). In addition, the rate of cannabalism in chaetognaths increases with increasing size of chaetognath (Pearre 1980). Midwater chaetognaths, which are large relative to epipelagic species, may therefore prey on their own group more frequently, producing pellets containing chaetognath remains. These are likely to be less dense than pellets containing phytoplankton remains, and therefore sink more slowly.

Because they sink more slowly, chaetognath pellets may more readily become entrained in the mixed layer, eaten, or decomposed, and, as a result, be less important to flux than similarly sized herbivore pellets in the environment. Nonetheless, chaetognath pellets may be produced consistently in great enough abundances to significantly contribute to carbon flux. We used a pellet production rate and animal abundances integrated over the depths of interest (the euphotic zone and midwater zone, for this study) to obtain an estimate of fecal carbon production which can be then compared to trap-derived carbon fluxes (see Small et al. 1989). (There are differences in feeding, digestion time, prey type and so on among species in nature, but for the sake of simplicity, one pellet production rate was used for all species of chaetognaths in each depth zone, as described in 'Results'.)

$$
\begin{aligned}
& \text { Fecal carbon production rate }\left(\mathrm{mg} \mathrm{C} \mathrm{m} \mathrm{m}^{-2} \mathrm{~d}^{-1}\right)= \\
& \text { mg } \mathrm{C} \text { pellet }{ }^{-1} \times \text { no. of pellets ind. }{ }^{-1} \mathrm{~d}^{-1} \\
& \times \text { no. of ind. } \mathrm{m}^{-3} \times \text { height of zone }(\mathrm{m})
\end{aligned}
$$

A carbon content of $0.9 \mu \mathrm{g} \mathrm{C}$ pellet $^{-1}$ and 2 pellets produced $\mathrm{d}^{-1}$ were used in Eq. 1 (above) for the euphotic zone. The euphotic zone depth was assumed to be $100 \mathrm{~m}$. For the midwater calculations, $45.8 \mu \mathrm{g} \mathrm{C}$ pellet $^{-1}$ and 1 pellet $d^{-1}$ were used. The midwater zone was assumed to start at $500 \mathrm{~m}$ and be $400 \mathrm{~m}$ deep. This zone depth was arbitrarily chosen to approximate the depth that the pellets might sink in $1 \mathrm{~d}$. Chaetognath abundances ranged greatly depending on season, geographic location, and production regime. A range of published values was used in Eq. 1 to determine maximum and minimum contributions to flux.

Since the total flux from the euphotic zone varies greatly from oligotrophic to upwelling regimes, the potential contribution of chaetognaths to particulate flux varied as well (Table 3 ). The fecal carbon production rate in the euphotic zone of the upwelling region ranged from 2.8 to $10.8 \mathrm{mg} \mathrm{C} \mathrm{m}{ }^{-2} \mathrm{~d}^{-1}$ If all pellets were to sink out of the euphotic zone, they would contribute 1.1 to $4.2 \%$ of the total particulate carbon flux at $100 \mathrm{~m}$. In the oligotrophic region the fecal carbon production rate was $2.1 \mathrm{mg} \mathrm{C} \mathrm{m} \mathrm{m}^{-2} \mathrm{~d}^{-1}$, which would contribute $5.9 \%$ of the total particulate carbon flux at $100 \mathrm{~m}$. Even though the total particulate carbon flux was less in the oligotrophic region, the number of individuals $\mathrm{m}^{-3}$ was also much less, so the fecal carbon production rate did not increase by a large proportion. If some of the pellets remain neutrally or positively buoyant in situ, this downward flux estimate would be reduced. 
Table 4. Potential percent contribution of chaetognath fecal pellets to carbon flux out of the midwater zone in 2 production regimes

\begin{tabular}{|c|c|c|}
\hline & $\begin{array}{l}\text { Upwelling region } \\
\text { (Coastal California) }\end{array}$ & $\begin{array}{c}\text { Oligotrophic region } \\
\text { (North Pacific Central Gyre) }\end{array}$ \\
\hline Carbon ( $u$ g pellet $\left.{ }^{-1}\right)$ & $45.8^{\mathrm{a}}$ & $45.8^{\circ}$ \\
\hline No of pellets $\mathrm{d}^{-1}$ & $1^{\mathrm{b}}$ & 1 \\
\hline Total peliet $C\left(\mu \mathrm{g}\right.$ ind. ${ }^{-1}$ ) & 45.8 & 45.8 \\
\hline No. of ind. $\mathrm{m}^{-3}$ in zone from 500 to $900 \mathrm{~m}$ depth & $0.01-0.12^{\mathrm{c}}$ & $.01^{\mathrm{d}}-.14^{\mathrm{e}}$ \\
\hline Fecal carbon production rate $\left(\mathrm{mg} \mathrm{m} \mathrm{m}^{-2} \mathrm{~d}^{-1}\right)$ & $0.2-2.2$ & $0.2-2.6$ \\
\hline $\begin{array}{l}\text { Total daily particulate flux out of mesopelagic zon } \\
\text { at } 900 \mathrm{~m}\left(\mathrm{mg} \mathrm{C} \mathrm{m}^{-2} \mathrm{~d}^{-1}\right)\end{array}$ & $37.3^{1}$ & $4.5^{\mathrm{f}}$ \\
\hline$\%$ pellet of total flux & $0.5-5.9$ & $4.4-57.7$ \\
\hline \multicolumn{3}{|c|}{$\begin{array}{l}\text { - Fecal pellets were assumed to be identical in this region for purposes of this estimate. See text for further assumptions } \\
\text { a This study; }{ }^{b} \text { Estimated, see text; }{ }^{c} \text { Alvariño }(1967) ;{ }^{d} \text { Pieper }(1967) \text {; }{ }^{e} \text { Lyons }(1976) \text {, numbers from 'Aries' cruise for } 5 \text { specie } \\
\text { with median depth greater than } 200 \mathrm{~m}^{\prime}{ }^{\prime} \text { Martin et al. (1987) using function } F_{z}=F_{100}(z / 100)^{b} \text {, with } b \text { specific to each VERTE } \\
\text { station }\end{array}$} \\
\hline
\end{tabular}

The potential contribution of chaetognath fecal pellets to flux from the midwater zone, although more variable, can be relatively large when compared with the contribution of pellets produced in the euphotic zone (Table 4). In an upwelling region, the chaetognath fecal carbon production rate could be 0.2 to $2.2 \mathrm{mg} \mathrm{C}$ $\mathrm{m}^{-2} \mathrm{~d}^{-1}$, or 0.5 to $5.9 \%$ of the total flux at $900 \mathrm{~m}$, and 0.2 to $2.6 \mathrm{mg} \mathrm{C} \mathrm{m}^{-2} \mathrm{~d}^{-1}$, or 4.4 to $57.7 \%$ of the total flux at $900 \mathrm{~m}$ in an oligotrophic region. The wide range in these calculations results from high variations in chaetognath abundance in the mesopelagic zone. The calculations would benefit from a more refined measurement of chaetognath abundance in the mesopelagic zone as well as from a study of digestion time in these larger organisms to better determine a daily prey ration and hence pellet production rate.

Using the particulate organic carbon (POC) : pigment ratio in total suspended particles versus phytoplankton alone, Small et al. (1989) inferred that omnivorous and carnivorous zooplankton in the Southern California Bight must contribute to fecal pellet production. While the calculations of the present study are merely estimates, they indicate that predator pellets may indeed play a significant role in the carbon budget. Sediment trap studies have not identified chaetognath fecal pellets as a flux component, but since they resemble copepod corpses or other zooplankton remains, they may be missed when the trap sample is counted. Moreover, even though pellets have high sinking speeds in the lab, they may be kept from sinking in the field by mixing (Alldredge et al. 1987). While this may be likely for pellets in the euphotic zone, it is less likely for pellets in the midwater zone, where little turbulence occurs. If chaetognath pellets are not in fact sedimenting out, then they must be eaten, decomposed, or otherwise recycled within the water column.
Acknowledgements. Special thanks to $\mathrm{E}$. Thuesen for identifying species, and to J. J. Childress for cruise time. We also gratefully acknowledge C. Gotschalk, K. Crocker, U. Passow and D. Smith for helping with chaetognath collection. This work was supported by NSF grant OCE 89-22825 to A.A. and by an NSF Graduate Research Fellowship to L.D

\section{LITERATURE CITED}

Alldredge, A. L., Gotschalk, G. C., Macintyre, S. (1987). Evidence for sustained residence of macrocrustacean fecal pellets in surface waters off Southern California. Deep Sea Res. 34: 1641-1652

Alvariño, A. (1967). Bathymetric distribution of chaetognatha, siphonophora, medusae, and ctenophora off San Diego, California. Pacif. Sci. 21: 474-485

Anderson, V., Nival, P. (1988). A pelagic ecosystem model simulating production and sedimentation of biogenic particles: role of salps and copepods. Mar. Ecol. Prog. Ser. 44: $37-50$

Bruland, K. W., Silver, M. W. (1981). Sinking rates of fecal pellets from gelatinous zooplankton (Salps, Pteropods, Doliolids). Mar. Biol. 63: 295-300

Childress, J. J., Barnes, A. T., Quetin, L. B., Robison, B. H. (1978). Thermally protecting cod ends for the recovery of living deep-sea animals. Deep Sea Res. 25: 419-422

Childress, J. J., Nygaard, M. (1974). Chemical composition and buoyancy of midwater crustaceans as function of depth of occurrence off Southern California. Mar. Biol. 27: $225-238$

Feigenbaum, D. (1979). Daily ration and specific daily ration of the chaetognath Sagitta enflata Mar. Biol. 54: 75-82

Fiedler, P. C. (1983). Fine-scale spatial patterns in the coastal epiplankton off Southern California. J. Plankton Res. 5: $865-879$

Fowler, S. W., Knauer, G. A. (1986). Role of large particles in the transport of elements and organic compounds through the oceanic water column. Prog. Oceanogr. 16: 147-194

Honjo, S., Roman, M. R. (1978). Marine copepod fecal pellets: production, preservation and sedimentation. J. mar. Res. 36: 45-57 
Knauer, G. A., Redalje, D. G., Harrison, W. G., Karl, D. M. (1990). New production at the VERTEX time-series site. Deep Sea Res. 37: 1121-1134

Komar, P. D., Morse, A. P., Small, L. F. (1981). An analysis of sinking rates of natural copepod and euphausiid fecal pellets. Limnol. Oceanogr. 26: 172-180

Kuhlmann, D. (1977). Laboratory studies on the feeding behavior of the chaetognaths Sagitta setosa J. Müller and $S$. elegans Verrill with special reference to fish eggs and larvae as food organisms. Meeresforsch. 25: 163-171

Lyons, H. W (1976). Seasonality in Central North Pacific chaetognaths. Ph.D. dissertation, Scripps, University of California, San Diego

Martin, J H., Knauer, G. A., Karl, D. M., Broenkow, W. W. (1987). VERTEX: carbon cycling in the northeast Pacific. Deep Sea Res. 34: 267-285

Mullin, M. M. (1979). Spatial and temporal scales and patterns. In: Eppley, R. W. (ed.) Plankton dynamics of the Southern California Bight. Springer-Verlag, Berlin, p. 216-273

Mullin, M. M., Brooks, E. R., Reid, F. M., Napp, J., Stewart, E. F. (1985). Vertical structure of nearshore plankton off Southern Cailifornia: a sion an and larval food web. Fish. Bull. U.S. 83: $151-170$

Nagasawa, S. (1985). The digestive efficiency of the chaetognath Sagitta crassa Tokioka, with observations on the feeding process. J. exp. mar. Biol. Ecol. 87: 271-281

Pearre, S. Jr (1973). Vertical migration and feeding in Sagitta elegans Verrill. Ecology 54:300-314

Pearre, S. Jr (1980). Feeding by chaetognatha: aspects of inter- and intra-specific predation. Mar. Ecol. Prog. Ser. 7 : $33-45$

Pennington, J. T., Strathmann, R. R. (1990). Consequences of

This article was presented by K. Banse, Seattle, Washington, USA. the calcite skeletons of planktonic echinoderm larvae for orientation, swimming and shape. Biol. Bull. 179: 121-133

Pieper, R. E. (1967). Mesopelagic faunal discontinuities in the Eastern North Pacific. Final Report, ONR Contract Nonr. $4742(00)$. Sea Operations Dept, AC Electronics, Defense Research Labs, Santa Barbara, CA

Reeve, M. R., Cosper, T. C., Walter, M. A. (1975). Visual observations of the process of digestion and the production of faecal pellets in the chaetognath Sagitta hispida Conant. J. exp. mar. Biol. Ecol. 17: 39-46

Rudall, K. M. (1963). The chitin/protein complexes of insect cuticles. In: Beament, J. W. L., Treherne, J. E., Wigglesworth, V. B. (eds.) Advances in insect physiology, Vol. 1. Academic Press, London, p. 257-313

Small, L. F., Landry, M. R., Eppley, R. W., Azam, F., Carlucci, A. F. (1989). Role of plankton in the carbon and nitrogen budgets of Santa Monica Basin, California. Mar. Ecol. Prog. Ser. 56: $57-74$

Smayda, T. J. (1970). The suspension and sinking of phytoplankton in the sea. Oceanogr. mar. Biol. A. Rev. 8. $353-414$

Star, J. L., Mullin, M. M. (1981). Zooplankton assemblages in three areas of the North Pacific as revealed by continuous horizontal transects. Deep Sea Res. 28: 1303-1322

Szyper, J. P. (1978). Feeding rate of the chaetognath Sagitta enflata in nature. Est. coast. mar. Sci. 7: 567-575

Terazaki, M., Marumo, R. (1982). Feeding habits of the mesoand bathypelagic chaetognath, Sagitta zetesios Fowler. Oceanol. Acta 5(4): 461-464

Wiebe, P. H., Madin, L. P., Harbison, G. R., Philbin, L. M. (1979). Diel vertical migration by Salpa aspera and its potential for large scale organic matter transport to the deep sea. Mar. Biol. 53: 249-255

Manuscript first received: June 20, 1992

Revised version accepted: November 23, 1992 